\title{
Ei ung jente med magesmerter
}

\author{
Årsakene til magesmerter hos unge jenter er mange, og «det van- \\ legaste er vanlegast». Av og til viser pasienten seg å vere sjukare \\ enn fyrsteinntrykket tilseier, og når diagnosen er uklår, kan det vere \\ ei utfordring å tenkje vidt nok.
}

Se kommentar side 1202 og kunnskapsprøve på www.tidsskriftet.no/quiz

\author{
Ann Marit Gilje \\ amgilje@gmail.com \\ Barneklinikken \\ Kvinne- og barnedivisjonen \\ Stavanger universitetssjukehus

\section{Per Kristian Knudsen} \\ Barnemedisinsk akuttavdeling \\ Oslo universitetssykehus, Ullevål \\ Knut Øymar \\ Barneklinikken \\ Kvinne- og barnedivisjonen \\ Stavanger universitetssjukehus
}

Ei 12 år gammal jente med magesmerter vart innlagt ved kirurgisk avdeling ved lokalsjukehuset. Ho hadde kjent astma og hadde gjennomgått mononukleose og infeksjon med varicella-zoster-virus nokre månader tidlegare. Dei aktuelle magesmertene hadde vart $i$ om lag 14 dagar. Smertene starta til venstre for umbilicus og vandra til nedre høgre kvadrant. Smertene var konstante, utan utstråling og hadde innleggingsdagen blitt meir intense. Ho hadde fått feber, var slapp og kvalm og hadde hatt litt laus avføring. Ved innkomst hadde ho temperatur på $38,4^{\circ} \mathrm{C}$, blodtrykk på $125 / 80 \mathrm{~mm} \mathrm{Hg}$ og puls på 143 per minutt. Ho var palpasjonsøm under høgre kostalboge og litt sleppøm $i$ høgre fossa iliaca. Leveren var palpabel $2 \mathrm{~cm}$ under kostalbogen. Det var normale funn ved auskultasjon av hjarte og lunger.

Feber og magesmerter hos barn og unge er ei vanleg problemstilling. Ein vil i fyrste omgang vurdere tilstandar som appendisitt, gastroenteritt og pyelonefritt. Gynekologiske infeksjonar er aktuelle differensialdiagnosar hos jenter. Basal pneumoni kan presentere seg som akutt abdomen, men vil oftast ha tilleggssymptom frå luftvegar. Virale infeksjonar som til dømes influensa, mononukleose og hepatittar kan gje magesmerter. Kronisk inflammatorisk tarmsjukdom kan også debutere med magesmerter og feber. I ein del tilfelle går plagene over utan at ein har funne noka årsak.

Urinstiks og humant choriongonadotropin (HCG) i urin var negative. Blodprøvar viste $C$-reaktivt protein (CRP) $57 \mathrm{mg} / \mathrm{l} /<10 \mathrm{mg} / \mathrm{ll}$ ), og hematologiske prøvar, elektrolyttar, nyreog leverprøvar var normale. Ultralyd abdomen viste normale forhold. Gynekologisk tilsyn gav inga forklaring på smertene. Tre dagar seinare vart jenta overflytta til Barneklinikken for vurdering. I løpet av det neste døgnet kom ho seg noko av smertene, feberen gjekk ned og CRP-verdien fall til $38 \mathrm{mg} / \mathrm{l}$. Det var ingen vekst i blodkultur og det vart ikkje påvist virus, tarmpatogene bakteriar eller parasittar $i$ avføring. Ho vart skriven ut med diagnosen uspesifisert virusinfeksjon.

Fire dagar seinare vart ho reinnlagt på grunn av forverring $i$ allmenntilstanden. Ho hadde framleis magesmerter og hadde i tida etter utskriving hatt litt hoste.

Ved innkomst var det normal respirasjon og normale auskultasjonsfunn over lungene. Det var ingen lymfeknutesvulst. Ho var palpasjonsøm i nedre høgre kvadrant av abdomen. Temperaturen var $38,3^{\circ} \mathrm{C}$. CRP var $49 \mathrm{mg} / \mathrm{l}$ og senkingsreaksjonen $25 \mathrm{~mm} / \mathrm{t}$ (< $10 \mathrm{~mm} / \mathrm{t}$ ). Dei andre blodprøvane var normale. Kalprotektin i avføring var $30 \mathrm{mg} / \mathrm{kg}$ $(0-50 \mathrm{mg} / \mathrm{kg})$. Røntgen av thorax viste sparsomme retikulonodulære fortettingar $i$ båe lunger (fig 1). Spirometri viste nedsett lungefunksjon med restriktivt preg og nedsett diffusjonskapasitet (tab 1). Det vart så gjort høgoppløysings-CT av thorax som viste multiple små noduli med tilfeldig distribusjon $i$ båe lunger, konsolidering $i$ venstre underlapp og forstørra lymfeknutar i mediastinum og hilus (fig 2). MR av abdomen utan kontrast viste normale forhold.

Vi mistenkte på dette tidspunktet pneumonitt eller annan interstitiell lungesjukdom. Retikulonodulære fortettingar i lungene med tilfeldig distribusjon samt mediastinal lymfadenopati gav mistanke om hematogen spreiing av virus, sopp eller tuberkulose. Sarkoidose og immunologiske tilstandar med lungeaffeksjon var også aktuelle differensialdiagnosar sjølv om ein ved sarkoidose oftast vil sjå ein meir peribronkial og perivaskulær distribusjon av noduli.

Ifølge pårørande var pasienten blitt tynnare dei siste månadene, og ho hadde no uttalt nattesveitte.

Vi sendte CT-bilete til Rikshospitalet for vurdering. Immunoglobuliner og revmatologiske prøvar var normale. Det vart påvist IgG-antistoff og IgG-EBNA-antistoff mot Epstein-Barr-virus, men ikkje IgM-antistoff. Ho hadde også IgG-antistoff mot cytomegalovirus. Det vart ikkje påvist antistoff mot Mycoplasma pneumoniae, Chlamydia pneumoniae, Borrelia burgdorferi eller Aspergillus fumigatus. Angiotensinkonverterande enzym i serum var på $69 \mathrm{U} / \mathrm{l}(9-85 \mathrm{U} / \mathrm{l})$. Lym-

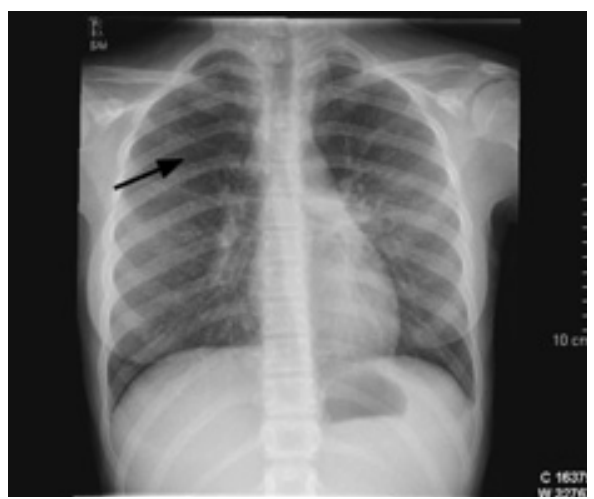

Figur 1 Røntgen av thorax tatt før behandlingsstart viser sparsomme retikulonodulære fortettingar $i$ båe lunger (pil)

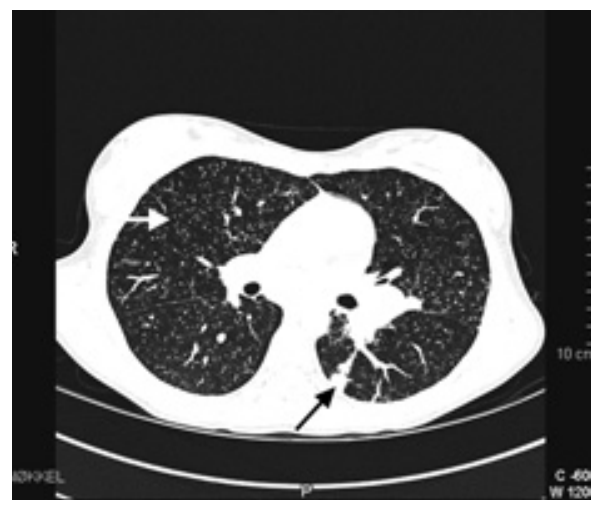

Figur 2 Høgoppløysings-CT av thorax tatt før behandlingsstart viser multiple små noduli med tilfeldig distribusjon i båe lunger (kvit pil), konsolidering i venstre underlapp (svart pil) og forstørra lymfeknutar i mediastinum og hilus 
Tabell 1 Resultat frå spirometri utført før behandlingsstar

\begin{tabular}{lccc|} 
& Målt & $\begin{array}{c}\text { Referanse- } \\
\text { verdi }\end{array}$ & $\begin{array}{c}\% \text { av referanse- } \\
\text { verdi }\end{array}$ \\
\hline Forsert vitalkapasitet (FVC) & $2,29 \mathrm{l}$ & $3,07 \mathrm{l}$ & 74 \\
\hline Forsert ekspiratorisk volum på eitt sekund $\left(\mathrm{FEV}_{1}\right)$ & $2,09 \mathrm{l}$ & $2,92 \mathrm{l}$ & 71 \\
\hline $\mathrm{FEV}_{1} / \mathrm{FVC}$ & $91 \%$ & $86 \%$ & \\
\hline Total lungekapasitet & $3,65 \mathrm{l}$ & $4,01 \mathrm{l}$ & 91 \\
Vitalkapasitet & $2,29 \mathrm{l}$ & $3,07 \mathrm{l}$ & 74 \\
Residualvolum & $1,36 \mathrm{l}$ & $0,85 \mathrm{l}$ & 160
\end{tabular}

focyttkvantitering viste noko reduserte nivå av T-hjelpeceller (CD4) og naturlege drepeceller (CD16/56). Vi fekk så melding frå Rikshospitalet om at CT-bileta mest sannsynleg viste miliær tuberkulose. Mantoux-test vart dagen etter avlese til $13 \mathrm{~mm}(<6 \mathrm{~mm})$.

Forverring i allmenntilstand og kliniske funn gav mistanke om alvorleg systemsjukdom. Serologisk var det ikkje haldepunkt for aktiv infeksjon med Epstein-Barr-virus eller cytomegalovirus, men funna tydde på tidlegare gjennomgåtte infeksjonar. Angiotensinkonverterande enzym i serum vil ofte vere forhøya ved sarkoidose. Lymfocyttkvantitering vart gjort fordi CT-funnet gav mistanke om ein type infeksjon som ein ser hos pasientar med nedsett immunforsvar.
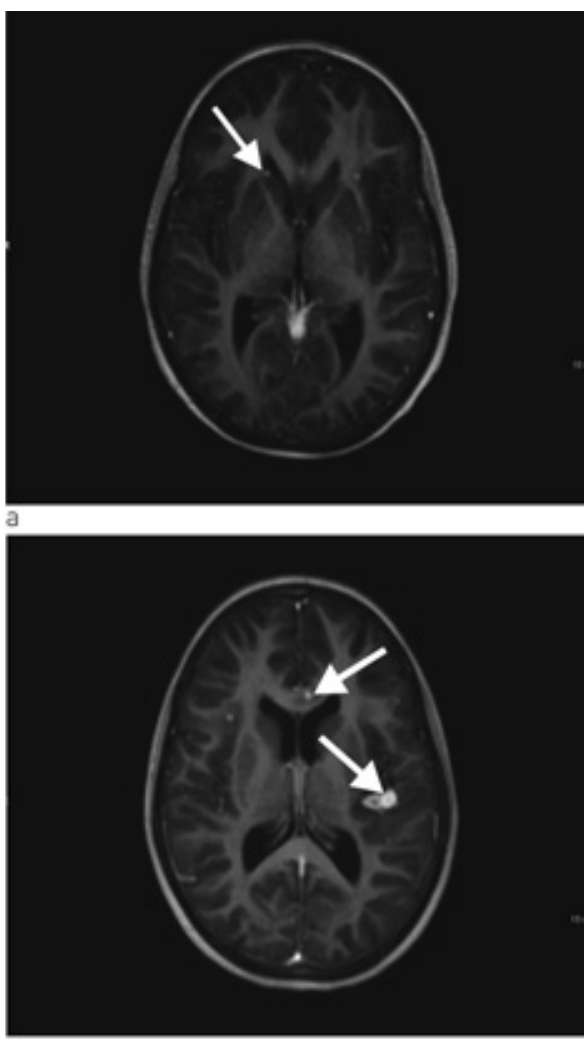

Figur 3 MR av cerebrum med kontrast. a) Bilete tatt før behandlingsstart viser multiple små kontrastladande lesjonar i overgangen mellom grå og kvit substans (pil). b) Bilete tatt to månader etter behandlingsstart viser at dei intrakraniale tuberkuloma har auka i storleik (piler)
Spørsmålet om eksponering for tuberkulose var gjentatte gongar tatt opp med pasient og pårørande, men med negativt resultat. Det vart hevda at alle nære pårørande var friske, og ingen av dei eldre i slekta hadde hatt tuberkulose tidlegare. Jenta hadde ikkje vore $\mathrm{i}$ høgendemiske område for tuberkulose eller i nærkontakt med innvandrarmiljø. Positiv Mantoux-test kan også skuldast infeksjon med atypiske mykobakteriar eller tidlegare BCG-vaksine (1). Pårørande meinte at jenta ikkje var vaksinert. Ein tydeleg positiv tuberkulinreaksjon hos ei jente med slike symptom og lungefunn talte likevel for tuberkulose sjølv om vi på dette tidspunktet ikkje hadde funne noka smittekjelde. Miliær tuberkulose er ein disseminert tuberkuløs infeksjon som har fått namn etter det typiske røntgenbiletet med små, utbreidde fortettingar som ser ut som hirsefrø (millet seed).

Ei veke etter innlegging var jenta klinisk dårlegare. Ho var kvalm og hadde svært redusert matlyst. Vi starta difor med intravenøs væsketilførsel og ernæring. Det vart tatt indusert sputum og gastrisk aspirat til direkte mikroskopi, PCR og dyrking med tanke på Mycobacterium tuberculosis. Vi rekvirerte også ein Quantiferon-TB Gold test. Dagen etter vart ho spinalpunktert, og vi fann leukocyttar $444 \cdot 10^{6} / l \quad\left(<3,0 \cdot 10^{6} / l\right)$, $80 \%$ polynukleære og $20 \%$ mononukleære, glukose $3,2 \mathrm{mmol} / \mathrm{l}$ og protein $0,31 \mathrm{~g} / \mathrm{l}$ < $0,50 \mathrm{~g} / \mathrm{l})$. På mistanke om miliær tuberkulose med meningitt starta vi med standard antituberkuløs behandling med isoniazid, rifampicin, pyrazinamid og etambutol samt pyridoksin. Dagen etter vart det i tillegg starta med intravenøs cefotaksimbehandling. Tre dagar seinare vart det gjort MR av cerebrum, som viste multiple små kontrastladande lesjonar i hjerneparenkymet, dei fleste i overgangen mellom grå og kvit substans, og i tillegg ein lesjon i basalgangliene på venstre side (fig 3a). Det var minst 16 lesjonar supratentorialt og tre infratentorialt, og den største målte $5 \mathrm{~mm}$ i diameter. Det vart gjort ekkokardiografi som viste normale forhold. Det vart ikkje påvist antistoff mot humant immunsviktvirus (hiv).

Tuberkuløs meningitt vil vanlegvis føre til forhøya proteinnivå i spinalvæska. Glukosenivået i spinalvæska kan vere normalt tidleg i forløpet av tuberkuløs meningitt, men er oftast lågt i seinare stadium. Vår pasient hadde ikkje låge glukoseverdiar og hadde normalt proteinnivå i spinalvæska. På grunn av den diagnostiske uvissa fekk jenta i tillegg behandling med cefotaksim. Funna på MR cerebrum kunne passe med tuberkulom, men kunne også gje mistanke om metastasar eller septiske emboliar. Det vart difor gjort ekkokardiografi for å utelukke endokarditt.

Quantiferon-TB Gold er ein interferon- $\gamma-$ basert test som i ein enkelt fullblodsprøve ved hjelp av ELISA-teknikk måler om testpersonens T-lymfocyttar er sensibiliserte mot $\mathrm{M}$ tuberculosis. Resultatet er ikkje påverkeleg av BCG-vaksine eller dei vanlegaste atypiske mykobakteriane, og testen har høgare spesifisitet enn tuberkulintesten for diagnostikk av tuberkulose (2). Testen skil ikkje mellom aktiv sjukdom og latent tuberkulose og er difor mest aktuell i lågendemiske område. Hos små born og personar med svekka immunforsvar har QuantiferonTB Gold lågare sensitivitet, og det er gjort færre studiar av desse gruppene. Ved sterk klinisk mistanke om tuberkulose og negativ eller inkonklusiv Quantiferon-TB Gold-test, tilbyr Folkehelseinstituttet ein annan interferon- $\gamma$-basert test (T-Spot TB) som har høgare sensitivitet hos desse pasientgruppene.

På grunn av usikker diagnose og komplisert sjukdom vart barnet dagen etter MR-undersøkinga overført til eit anna universitetssjukehus. Vi fekk så svar på Quantiferon-TB Gold som var $5,17 \mathrm{IU} / \mathrm{ml}(<0,35 \mathrm{lU} / \mathrm{ml}$. Augelege fann at jenta hadde korioretinale infiltrat bilateralt. MR av abdomen med kontrast viste hepatosplenomegali utan fokal patologi samt forstørra lymfeknutar $i$ leverhilus og paraaortalt. 13 dagar etter overføring kom det melding om positiv polymerasekjedereaksjonstest (PCR) for M tuberculosis-komplekset $i$ indusert sputum. Ei veke seinare vart det stadfesta vekst av M tuberculosis i indusert sputum og i spinalvæske. Stammen var sensitiv for alle testa medikament. Etter 14 dagar vart jenta overført til lokalsjukehuset. Røntgen av thorax etter to månaders behandling viste markert tilbakegang av lungefortettingane. Samstundes vart det tatt ein kontroll-MR av cerebrum som viste at dei intracerebrale lesjonane hadde auka i storleik og at det var fleire nytilkomne lesjonar (fig 3b). Jenta var framleis innlagt i avdelinga. Ho hadde ingen nyoppståtte nevrologiske symptom eller utfall. Visuelt framkalte potensial (VEP), som er ein spesifikk test av nervus opticus, vart undersøkt tidleg $i$ behandlingsforløpet og etter åtte veker. Funna ved desse undersøkingane var normale.

Quantiferon-TB Gold var tydeleg forhøya og talte sterkt for tuberkulose. $70 \%$ av born med miliær tuberkulose har korioretinale infiltrat, og dette reknar ein som patognomonisk (3). Positiv PCR for M tuberculosiskomplekset $\mathrm{i}$ indusert sputum samt vekst av 
M tuberculosis i ekspektorat og spinalvæske gav endeleg diagnose. Ho fekk empirisk behandling med fire medikament dei fyrste to månadene på grunn av utbreidd sjukdom og meningitt, sjølv om stammen ikkje var resistent. Etter gjeldande anbefalingar fekk ho tilskot med pyridoksin (vitamin $\mathrm{B}_{6}$ ) i heile behandlingsperioden for å forebygge perifer nevropati som biverknad av isoniazid. Visuelt framkalte potensial vart undersøkt fordi behandling med etambutol kan gje nervus opticus-nevritt.

Pyrazinamid og etambutol vart seponert etter to månader og ho fekk behandling med isoniazid, rifampicin og pyridoksin i ytterlegare ti månader. Medikamenta vart i heile behandlingsperioden gjevne som direkte observert terapi (DOT). Det vil seie at helsepersonell leverte ut medisinane og observerte at pasienten tok dei. Etter to og ein halv månad $i$ sjukehus kunne jenta skrivast ut til heimen i god allmenntilstand.

Ved smitteoppsporing i heimkommunen viste det seg at ein person i nær relasjon til familien hadde forhøya verdiar ved Mantoux-test på $22 \mathrm{~mm}$, kaverner på røntgen av thorax og oppvekst av M tuberculosis $i$ indusert sputum.

Ved kliniske kontrollar to, åtte og tolv månader etter utskriving var det tilfredsstillande forhold. MR av cerebrum etter sju månader med behandling viste nær komplett tilbakegang av alle lesjonar. Dei korioretinale infiltrata gjekk også fullstendig tilbake. Lymfocyttpopulasjonar vart kontrollert på same tidspunkt og viste no tilnærma normale verdiar.

\section{Diskusjon}

Miliær tuberkulose og tuberkuløs meningitt er uvanlege former for tuberkulose i Noreg. Miliær tuberkulose utgjer 1-2\% av all tuberkulose globalt, men i dei yngste aldersgruppene og blant immunsupprimerte er førekomsten høgare (3). Mindre enn $0,5 \%$ av born over ti år vil utvikle disseminert tuberkuløs infeksjon etter smitte (4). Ved miliær tuberkulose vil opptil $50 \%$ av pasientane ha sentralnervøs affeksjon og då hovudsakleg som meningitt. Kombinasjonen meningitt og tuberkulom finst hos opptil $10 \%$ av pasientar med sentralnervøs tuberkulose (3).

Vanlege symptom på miliær tuberkulose er feber, hoste, vekttap, anoreksi og nattesveitte (3). Ein vil ofte finne hepatomegali, splenomegali og lymfadenopati. Vår pasient hadde alle desse symptoma, men i starten var hosten lite uttalt og det var relativt få kliniske funn. Tuberkuløs meningitt er delt inn i tre stadier, der stadium 1 inneber uspesifikke symptom som hovudverk, kvalme, magesmerter og feber (5). I stadium 2 ser ein meningeal irritasjon og hjernenerveutfall, og i stadium 3 vil pasienten ha forhøya intrakranialt trykk og påverka medvit (3). Vår pasient vart diagnostisert i stadium 1 .

Dei intrakraniale lesjonane auka i storleik etter to månader med behandling, og det hadde tilsynelatande oppstått nye lesjonar. Dette fenomenet er skildra i litteraturen (6). Årsaka er ikkje godt kjent, men representerer sannsynlegvis ein immunrespons på frisette antigen frå M tuberculosis. Slik paradoksal auke i tuberkulom utgjer ikkje indikasjon for å endre behandlingsopplegg med mindre pasienten har nevrologiske symptom eller utfall (6).

I internasjonale retningslinjer er det anbefalt behandling med kortikosteroider den første tida ved tuberkuløs meningitt (7). Vi vurderte slik behandling, men fann ikkje indikasjon for dette, då jenta ikkje hadde nevrologiske utfall eller påverka mental status. Seinare har det kome britiske retningslinjer som anbefaler tilleggsbehandling med kortikosteroider i 6-8 veker til alle pasientar med tuberkuløs meningitt uavhengig av det kliniske biletet (8). Anbefalt behandlingslengd for meningeal tuberkulose er minst 12 månader. Vidare er det anbefalt å gje fire medikament i høgare dose enn vanleg dei første to månadene (intensivfasen), også ved fullt sensitiv bakteriestamme (8).

Kvifor fekk så ein 12-åring disseminert infeksjon etter å ha blitt smitta med tuberkulose? Eit slikt sjukdomsforløp ser ein gjerne hos pasientar med hivinfeksjon eller annan immunsvikt, hos underernærte eller små born. Virale infeksjonar kan gje forbigåande immunsuppresjon som kan disponere for systemisk infeksjon $(5,9)$. Vår pasient hadde ikkje antistoff mot hiv. Gjennomgang av jenta sitt kosthald gav ikkje mistanke om underernæring. Ho hadde hatt mononukleose eit par månader før sjukdomsdebut. Like etter fekk ho varicellainfeksjon. Då ho vart sjuk av tuberkulose, hadde ho påviseleg immunsuppresjon i form av redusert tal på T-hjelpeceller, noko vi i ettertid tolka som eit utslag av tuberkulosen. Positiv QuantiferonTB Gold og normalisering av lymfocyttpopulasjonane etter behandling tydde på intakt cellulær immunitet. Det var såleis ikkje gjort unormale funn knytt til jenta sitt immunforsvar, men det er mogleg at infeksjon med Epstein-Barr-virus og varicella zoster-virus i tett rekkefølge kan ha påverka immunforsvaret og medverka til disseminering av tuberkuløs infeksjon.

Smittekjelda vart funne om lag ein månad etter behandlingsstart, og var ein nærkontakt. Dette kom fram fyrst etter aktiv smitteoppsporing i heimkommunen. Det hadde vore meir nærliggande å mistenke tuberkulose dersom denne opplysninga hadde kome fram tidlegare. Eit viktig moment er at denne personen opplevde seg som frisk.

Trass $\mathrm{i}$ låg prevalens av tuberkulose $\mathrm{i}$ Noreg illustrerer sjukehistoria at ein framleis må tenkje på diagnosen, også hos norske personar. Manglande opplysningar om smitteeksponering bør ikkje avkrefte ein mistanke om tuberkulose. Ein grundig anamnese kan ikkje vektleggjast nok. Hos born må ein ofte starte behandling på klinisk mistanke før ein har sikre diagnostiske resultat.
Pasient og pårørande har gjeve samtykke til at artikkelen vert publisert.

Vi takkar Einar Kristoffersen ved Avdeling for mikrobiologi og immunologi, Haukeland universitetssjukehus, for analysar av lymfocyttpopulasjonar og verdifulle kommentarar knytt til det.

\section{Ann Marit Gilje (f. 1975)}

er spesialist i barnesjukdommar og er konstituert overlege ved Barneklinikken, Stavanger universitetssjukehus.

Ingen oppgjevne interessekonfliktar.

\section{Per Kristian Knudsen (f. 1965)}

er spesialist i barnesjukdommar og er overlege ved Barnemedisinsk akuttavdeling, Oslo universitetssykehus, Ullevål.

Ingen oppgjevne interessekonfliktar.

\section{Knut Øymar (f. 1959)}

er dr.med. og spesialist i barnesjukdommar. Han er avdelingsoverlege ved Barneklinikken, Stavanger universitetssjukehus og professor ved Institutt for klinisk medisin, Universitetet i Bergen.

Ingen oppgjevne interessekonfliktar.

Litteratur

1. Forebygging og kontroll av tuberkulose. En veileder. Oslo: Nasjonalt folkehelseinstitutt, 2002

2. Morland L, Gulsvik A. Nye analysemetoder av blod for påvisning av tuberkulose. Tidsskr Nor Lægeforen 2005; 125: 2995-6

3. Cruz AT, Starke JR. Clinical manifestations of tuberculosis in children. Paediatr Respir Rev 2007; 8: 107-17.

4. Newton SM, Brent AJ, Anderson S et al. Paediatric tuberculosis. Lancet Infect Dis 2008; 8: 498-510.

Yaramis A, Gurkan F, Elevli M et al. Central nervous system tuberculosis in children: a review of 214 cases. Pediatrics 1998; 102: E49.

6. Nicolls DJ, King M, Holland D et al. Intracrania tuberculomas developing while on therapy for pulmonary tuberculosis. Lancet Infect Dis 2005 5: 795-801.

7. National Collaboration Centre for Chronic Conditions. Tuberculosis: clinical diagnosis and management of tuberculosis, and measures for its prevention and control. London: Royal College of Physicians, 2006: 63-6, 74-5

8. Thwaites G, Fisher M, Hemingway $C$ et al. British Infection Society guidelines for the diagnosis and treatment of tuberculosis of the central nervous system in adults and children. J Infect 2009; 59: 167-87.

9. Powell DA, Hunt WG. Tuberculosis in children: an update. Adv Pediatr 2006; 53: 279-322.

Mottatt 14.7. 2009, første revisjon innsendt 25.4 2010, godkjent 6.1. 2011. Medisinsk redaktør Mette Sagsveen. 